\title{
International expansion of retailers: the role of technical expertise, alliances and allocation of resources in economic crises
}

\section{Authors: Eunyoung (Christine) Sung \& Tai Goebel}

This is a postprint of an article that originally appeared in International Journal of Technology

Marketing on May 2019. The final version can be found at DOI\# 10.1504/IJTMKT.2018.099858.

Sung, Eunyoung, and Tai Goebel. "International expansion of retailers: the role of technical expertise, alliances and allocation of resources in economic crises." International Journal of Technology Marketing 13, no. 1 (May 2019). DOI:10.1504/IJTMKT.2018.099858.

Made available through Montana State University's ScholarWorks 


\title{
International expansion of retailers: the role of technical expertise, alliances and allocation of resources in economic crises
}

\author{
Eunyoung Sung* \\ Jake Jabs College of Business and Entrepreneurship, \\ Montana State University, \\ 236 Jabs Hall, P.O. Box 173040, \\ Bozeman, Montana 59717, USA \\ Fax: 406-994-6206 \\ Email: ChristineSung@montana.edu \\ *Corresponding author
}

\section{Tia Goebel}

Interdisciplinary Studies, Honors College, Montana State University

Bozeman, Montana 59717, USA

Email: tia.goebel22@gmail.com

\begin{abstract}
Economic downturns are often viewed as threats to prosperity and the challenges they can pose for international retailers are well documented. However, the potential opportunities of economic downturns are less well understood. In this paper, we ask whether or how these environments might actually afford occasions for strategic market adjustment, in the form of international expansion to new markets. Specifically, drawing on resource-based theory and game theory, we consider how a firm's financial performance during international expansion in a downturn may be predicted by its engagement in three modes of knowledge transfer. We consider knowledge transfer enabled by: 1) long-term investment in technical expertise; 2) formation of alliances in the local target market; 3) focused allocation of firm resources. Based on cases from the 1997 Asian Financial Crisis, the 2007 US recession and the 2009 European Sovereign Debt Crisis, we developed propositions to guide future research on international expansion during economic downturns.
\end{abstract}

Keywords: economic downturn/crisis; international retailer; knowledge transfer; technical expertise; alliance; firm resources; resource-based theory; game theory.

Reference to this paper should be made as follows: Sung, E. and Goebel, T. $(\mathrm{xxxx})$ 'International expansion of retailers: the role of technical expertise, alliances and allocation of resources in economic crises', Int. J. Technology Marketing, Vol. X, No. Y, pp.xxx-xxx.

Biographical notes: Eunyoung (Christine) Sung is an Assistant Professor of Marketing, Jake Jabs College of Business and Entrepreneurship, Montana State University. She holds a PhD from the Michigan State University. 
Tia Goebel is an undergraduate student at the Montana State University. She was a Research Assistant for Dr. Sung for Fall 2016 Semester.

This paper is a revised and expanded version of a paper entitled 'Converting economic downturn into international expansion through firm resources, alliances, and knowledge transfer' presented at American Collegiate Retailing Association (ACRA) Conference, Boston, MA, 3-5 March 2011.

\section{Introduction}

An economic downturn can pose many threats to a business's prosperity. During a downturn, the demand for a retailer's product may be dampened, consumption may be reduced and competition may increase (Bacchetta and Gerlach, 1997; Butterworth, 2008). In addition, international retailers may see declines in consumer spending (Corsetti et al., 1999; Butterworth, 2008; McCoy, 2017), which necessitate that firms exercise particular wisdom and restraint in their use of resources. Whether the recession is in the international retailer's home country or in a host country (a foreign market where the firm operates), the recession can create an inhospitable environment of tight profit margins and heightened competition. Yet, paradoxically, environments of economic downturn may also encourage expansion in some circumstances, whether the economic crisis is in the host country or in the firm's own home country.

A crisis at home may 'push' the firm to expand outward, while a crisis abroad may 'pull' a firm into the crisis market, which tends to favour foreign firms. When the recession is in the host country, as Zhong and Lahiri (2009) have shown, a pull factor may occur, in which the host country opens its market and attempts to make it more attractive to foreign investors in order to boost its economy. For example, during the 1997 Asian economic crisis, the government in Korea implemented a three-year economic stimulus plan to boost its economy. Based on the General Agreement on Trade in Service (GATS), it implemented measures to attract foreign investors and liberalise the economy (Suh and Howard, 2009). These measures all enticed international firms to expand into Korea, such that the economic downturn in the host country (e.g., the 1997 Asian Financial Crisis) became an opportunity for international retailers to profit when entering into this host country. Both sides stood to benefit, as the firms were seeking to expand internationally and the host country was seeking to turn around its economy. Inversely, when it is the home county that is experiencing economic downturn, a push factor may occur, where conditions in the home country prompt the firm to look outward for more hospitable markets. A home market in economic crisis often experiences a rise in interest rates that makes it more expensive to buy products and supplies from vendors on credit. Moreover, some governments may attempt to turn the economy around by interfering in businesses' operations, imposing severe restrictions (Corsetti et al., 1999). For firms that rely on imported purchases from foreign brands, high exchange rates during economic crises can create an additional stressor as imports become more expensive. Amidst the many challenges of an economic downturn in a firm's home country, retailers might respond by restraining their use of resources, running their business operations as tightly as possible to weather the recession. 
Research has shown that a firm's performance following internationalisation depends on its knowledge management (Dawson, 2003). Firms' knowledge management has been recognised as an important strategic tool across companies for profitability (Khan and Roy, 2013). Retailers' performance is influenced by their development of knowledge resources and their conversion of these resources into the capability of market responsiveness (Griffith et al., 2006). In the process of internationalisation, a firm's engagement in knowledge transfer provides a crucial competitive advantage in foreign markets (Kogut and Zander, 1992, 1993), with the efficacy of a given knowledge transfer process depending on the characteristics of the knowledge being transferred (Chen, 2004).

Although the challenges of economic downturns for international retailers have been well documented, less is known about firms that overcome these challenges and how they do so. This paper considers both successful and unsuccessful cases of retailers' that expand internationally during downturns, defining success in terms of their financial performance. In particular, we look at firms' use of three distinct modes of knowledge transfer in their expansion efforts and how the use of these strategies may enable retailers to manoeuvre within the turbulent waters of a recession to execute their strategies for long-term growth and expansion. We consider cases of host countries 'pulling' firms in, as well as cases of home countries 'pushing' firms out. For both types of cases, we explore whether the key to firms' financial performance in their international expansion lies in whether or how they engage in knowledge transfer, defined as the systematic and intentional organisation, communication and dissemination of information and knowledge within an organisation, or between the organisation and an entity or environment outside the organisation, for the purpose of making that knowledge available to future users (Bresman et al., 1999; Bosch-Sijtsema and Postma, 2010; Nonaka and Takeuchi, 1995; Zander, 1991).

This paper is particularly concerned with firms' use of three specific knowledge transfer strategies that firms may use in the course of international expansion during economic downturns: their investment in developing technical expertise, their formation of temporary international alliances and their focused allocation of resources towards the goal of knowledge transfer. We consider these three modes of knowledge transfer and the financial success of firms' attempts to expand internationally during economic downturns. In order to explore the relationships of these strategies to firms' financial performance, we examine six retailer cases from three major economic downturns of the past twenty years: the Asian financial crisis that began in 1997, the US recession that began in 2007 and the European Sovereign Debt Crisis that began in late 2009. The cases include instances of both successful and unsuccessful knowledge transfer by retailers. Based on these cases, we provide three propositions to guide future research on international expansion during economic downturns. The three propositions advanced in this paper provide a framework for researchers investigating international retailers' options for expansion in economic downturn and they may also provide insights for international retailers developing strategies for expansion in similar economic conditions. Our paper's contribution to the knowledge transfer literature is two-fold:

- A comparative view of knowledge transfer strategies used by retailers in a variety of international expansion scenarios. 
- A close examination of three specific knowledge transfer strategies that have not yet been studied in the context of international retailers' expansion during economic downturn.

First, our paper investigates the performance of international retailers that used various forms of knowledge transfer during the major recent economic recessions on three continents, Asia, North America (the USA) and Europe. The cases in our paper include retailers for whom these recessions occurred in their home country (pushing them to expand to international markets) as well as those for whom the recessions occurred in the host countries to which they sought to expand (pulling to expand into these markets). By looking across continents and considering both home and host countries in recession, we are able to take a broad view of international expansion during economic downturns and consider how retailers' international expansion strategies are influenced by various contextual factors. Depending on whether the economic downturn is in a host country or the retailer's home country, retailers may be responding to either push or pull factors as they work to overcome the challenges associated with economic downturns. Previous studies have not taken such a comparative view of retailers' strategies, so our paper could yield important insights for retailers regarding what strategies are effective when using knowledge transfer in international expansion during a recession.

A second contribution of our study is our focus on three specific modes of knowledge transfer that have not yet been studied in relation to retailers' international expansion efforts in economic downturns. The three modes or forms of knowledge transfer we consider may be deployed by firms seeking to organise and communicate information within and beyond their own organisation. They are investment in technical expertise, formation of alliances with local partners and focused allocation of resources. Knowledge transfer is known to be an important source of competitive advantage for firms (Haspeslagh and Jemison, 1991), but the precise knowledge transfer strategies that are most effective in various circumstances are not fully understood. Our paper explores how international retailers can strategically use one or more of these three modes of knowledge transfer based on the location of the recession (host country versus retailer's home country) and the degree of cultural difference between the host and home country. These relationships are illuminated but not fully explained by existing theories and concepts, such as resource-based theory, game theory and the concept of knowledge transfer.

\section{Theoretical background}

This section defines the concepts of knowledge and knowledge transfer and presents the conceptual model of the current study (Figure 1). The model illustrates the relationships between three modes of knowledge transfer and the financial performance of firms expanding internationally in economic downturn.

Knowledge is here defined as the assemblage of practical skills or expertise that a firm accumulates over time and that make it possible for the firm to operate smoothly and efficiently (Sarala and Vaara, 2010). Knowledge transfer, the organised communication of that knowledge, is known to be an important component in value creation and contributes to firms' competitive advantage (Haspeslagh and Jemison, 1991). Knowledge transfer can be challenging for firms, however, because it requires the capture and 
articulation of information that resides in various disparate forms, whether the tacit knowledge contained in subconscious habits or the encoded knowledge contained in forms such as organisational processes and tools (Bhagat et al., 2002). Thus, the transfer of knowledge of any kind is especially difficult across geographic distance, cultural and language barriers and expertise domains, as well as in situations where information is faulty or trust is low.

Based on the proposed theoretical framework, this article advances three propositions to describe how international retailers might be able to successfully undertake international expansion during economic downturns. We propose that successful expansion efforts tend to be characterised by three modes of knowledge transfer: that which is facilitated by firms' prior investment in technical expertise, their formation of alliances with appropriate partners and their focused and strategic allocation of resources.

Figure 1 Three modes of knowledge transfer in relation to firms' financial performance when expanding internationally during economic downturn

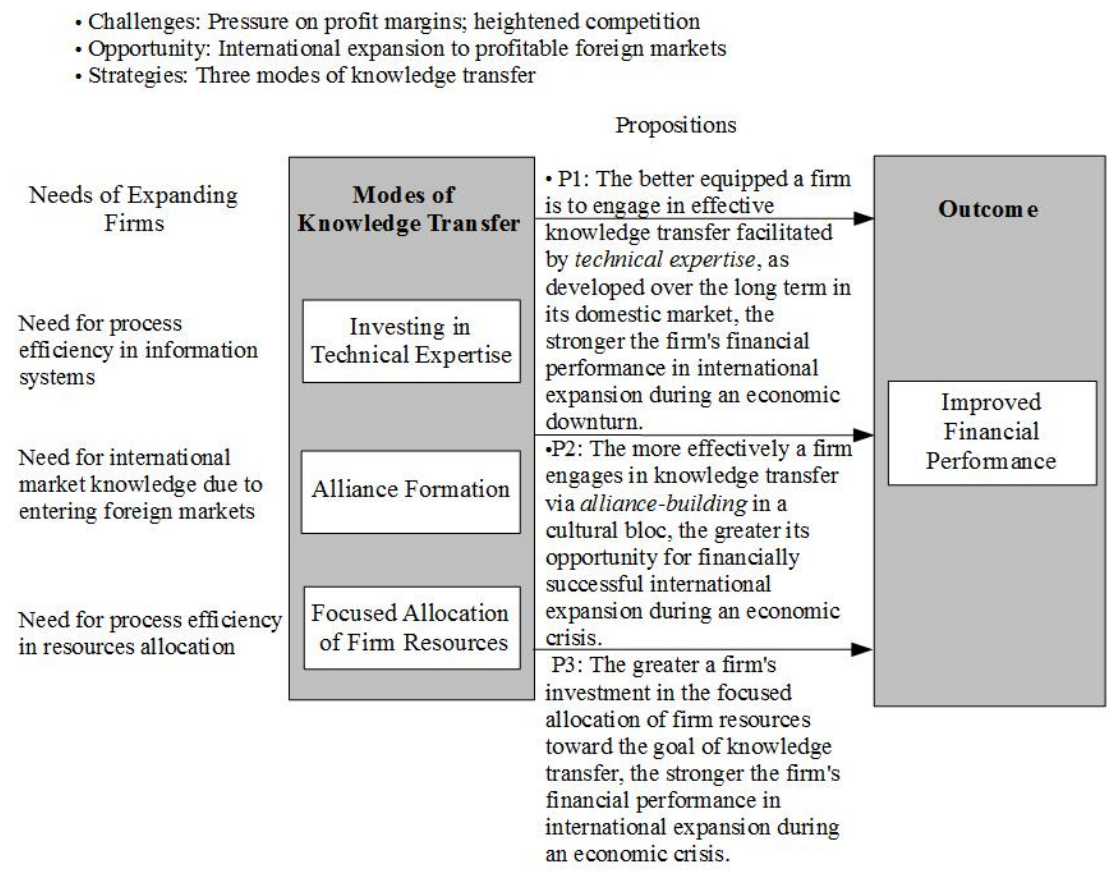

Whereas, Figure 1 depicts three modes of knowledge transfer that potentially improve firm performance in times of economic crisis, Table 1 displays relevant prior research, illustrating the trends in research on knowledge transfer and international expansion in economic crises. The table indicates each paper's methods and theoretical basis in order to show how the current study is distinct and clarify its contribution. 
6 E. Sung and T. Goebel

Table 1 Prior research on knowledge transfer

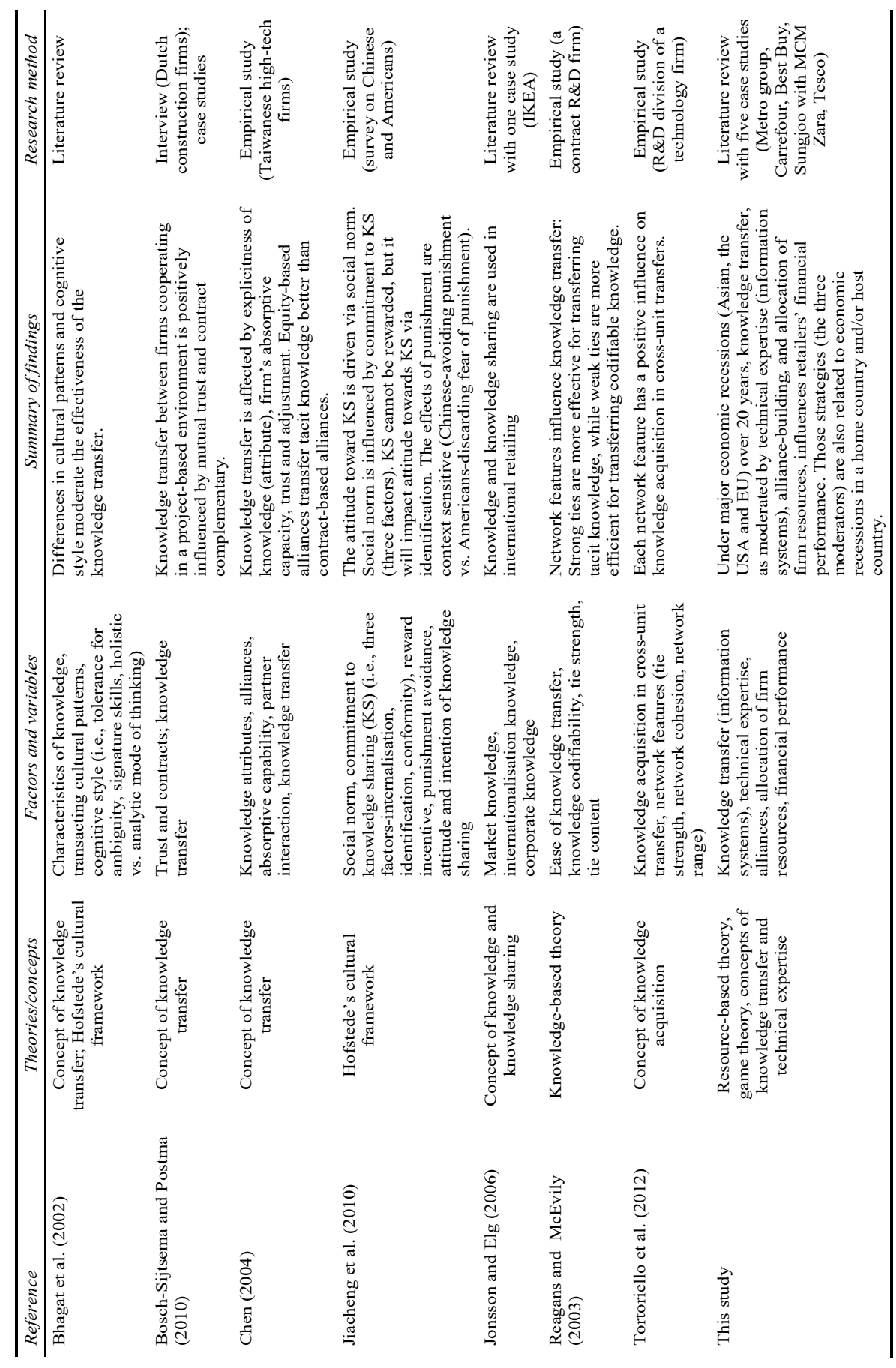




\section{Methodology}

The current study combines two methods: a multi-case study design (Bosch-Sijtsema and Postma, 2010; Eisenhardt, 1989; Hartley, 1994; Yin, 1994) and a literature review (Bhagat et al., 2002; Jonsson and Elg, 2006). The latter includes secondary data from articles and documents from firms and published articles (Bosch-Sijtsema and Postma, 2010) about retailing news.

For the case study component, the selection of cases was informed by propositions, theories and findings from previous research on economic recessions, as well as by news reports and publically accessible data sources. All six major global retailers were selected based on their sales and profits during a major economic recession in their region. Each of the chosen retailers was from an area that had experienced one of three major economic recessions of the past two decades, was among the top retailers in their country and had expanded their business across one of three continents (North America, Asia, or the EU) during one of the major economic recessions. The retailers that were selected all had had their performances detailed in news reports and publically accessible data sources using EBSCO Business Source Complete over the particular major economic crises of interest in the paper. In selecting and analysing these cases, the performance of many other international retailers over two decades of retailing news was also considered, paying particular attention to the period of the Asian, the USA and European recessions. The sources for the cases, which provided secondary data for analysis, are summarised in Table 2. Based on the cases and the literature review, three modes of knowledge transfer were identified as potential strategies for firms engaging in international expansion during economic downturn: technical expertise, local alliance formation and focused allocation of resources.

The first potential form of knowledge transfer we consider is firms' long-term investment in developing technical expertise, which can facilitate knowledge-sharing and the transfer of knowledge across and beyond the organisation. Specifically, we consider how international retailers engage in this sharing of technical expertise as they pursue international expansion into new markets during economic downturns. Technical expertise is defined as high-level understanding of a particular technology, such as the production process and affiliated technologies used to manufacture, develop, or deliver a certain product or service (Grant, 1996; Parmigiani and Mitchell, 2009, 2010). As an organisational capability, technical expertise develops over time (Barney, 1991; Szulanski, 1996) and can take the form of information systems, supply chain management systems, data networks, or other complex, specialised systems. In order for international retailers to engage in the adoption of new technology and other innovations, they must be able to share or exchange technical expertise with suppliers in the international market.

The second factor that we consider as a potential mode of knowledge transfer that may affect the financial success of an expansion effort during recession is the strategy of forming alliances with local partners in the host country. For retailers entering a new international market, especially one under economic recession, one of the main challenges in a host country is a cultural difference. However, this challenge may be surmounted by strategically forming relationships with local partners. Such partnerships can help firms locate potential expansion opportunities, determine the profitability of a given expansion effort and understand the nuances of the local market. 
The third mode of knowledge transfer that we consider as potentially impacting firms' financial performance during expansion is the focused allocation of firm resources. During a recession in a retailer's home county, the firm's access to resources may be restrained even as competition increases. The restrained situation requires firms to operate with heightened efficiency, a challenge that may be met by allocating firm resources in a strategic and focused way.

In mapping the relationships between three modes of knowledge transfer and firms' financial performance in economic crises, this paper draws on six cases. In each case, an international retailer responded to economic downturn in either a host country or the home country (or both) by attempting to expand internationally. The firms had varying degrees of success in their expansions. International retailers from Asian, American and European countries were chosen as examples and cases were drawn from three different major economic crises: the 1997 Asian Financial Crisis, the 2007 US recession and the 2009 European Sovereign Debt Crisis. The first case, Metro Group, a major German retail player in the EU market, provides an example of a firm spending years to develop technical expertise, in the form of a proprietary information system, in its domestic market of Germany, before using that expertise to expand internationally during the 2009 European Sovereign Debt Crisis. In the second case, the American electronics retailer Best Buy, a major American retail player in the North American market, made a less successful attempt to expand during the US's 2007 financial crisis, as its information system provided insufficient knowledge-sharing with suppliers and the retailer failed to build effective alliances. The third case is Tesco, the British-based international grocery retailer that is a major retail player in terms of profit and sales in the EU market. Tesco deployed exceptional technical expertise in the form of a customer relationship management (CRM) database system during the 1997 Asian Financial Crisis. The fourth case is Carrefour, an international grocery retailer headquartered in France that is a major retail player in the EU market. Carrefour created an alliance with IBM during the 2009 European Sovereign Debt Crisis so that the technology company could help it develop efficient management systems. The fifth case, Zara, is an international fast fashion retailer headquartered in Spain and a major player in the EU market. Zara used its technical expertise, an excellent supply chain management system, to connect its suppliers and stores during the European Sovereign Debt Crisis. The sixth case, Sungjoo International, transformed itself from a struggling local brand in Korea to a growing international luxury fashion retailer. By acquisitioning the luxury handbag brand MCM from Germany during the 1997 Asian financial crisis, Sungjoo was able to transfer knowledge via this acquisition and become one of the major luxury fashion retail players in the Asian market.

Taken together, these six cases illuminate the ways in which retailers may use three forms of knowledge transfer - investment in technical expertise, formation of local alliances and focused allocation of firm resources - in their strategies for international expansion as they seek to improve their financial performance during economic downturns. The goal of such knowledge transfer is to increase the company's understanding of new markets, customers and product transactions and thus contribute to the financial success of international expansion efforts. The conceptual study model was shown in Figure 1. Table 2 maps the three forms of knowledge transfer onto the retailer cases in which they were observed and indicates the sources used for each case. 
Table 2 Modes of knowledge transfer and associated retailer cases

\begin{tabular}{lcc}
\hline $\begin{array}{l}\text { Three modes of } \\
\text { knowledge transfer }\end{array}$ & Retailer case examples & Resources used \\
\hline $\begin{array}{l}\text { Investment in } \\
\text { technical expertise }\end{array}$ & $\begin{array}{c}\text { Metro Group including Cash } \\
\text { and Carry and Saturn } \\
\text { (information-sharing system } \\
\text { for supply chain management) }\end{array}$ & $\begin{array}{c}\text { Global data synchronisation network } \\
\text { (FierceRetail, 2008; Russia is Next in } \\
\text { the Move to Synchronise Data, 2009); } \\
\text { MicroStrategy (MicroStrategy, 2009; } \\
\text { Retail Technology, 2008) }\end{array}$ \\
& $\begin{array}{c}\text { Best Buy (information-sharing } \\
\text { system with vendors) }\end{array}$ & $\begin{array}{c}\text { Real-time in-sync data (Dvorak, 2009; } \\
\text { Business Bloomberg News, 2011; }\end{array}$ \\
& Tesco (CRM system) & Burkitt, 2014) \\
& & Clubcard (Rowley, 2005; Sung and \\
& Sternquist, 2010; Capron 1999; Capron \\
and Pistre, 2002)
\end{tabular}

\section{Literature review, case studies and proposition}

\subsection{Knowledge transfer, technical expertise and resource-advantage theory}

Different types of knowledge lend themselves to the use of different knowledge management processes between companies and in cases of intercultural knowledge transfer, this process may be particularly complex (Inkpen and Dinur, 1998). Chen (2004) recommends that for the transfer of explicit (e.g., codifiable) knowledge, companies should use technology sharing and that for the transfer of tacit (e.g., know-how) knowledge, personal transfer is most efficacious. Pisano (1998) notes that because a firm's technology involves highly tacit knowledge (e.g., technical expertise, such as technical competence in an information system) it is 'unsuitable to imitation' and therefore, technical expertise can provide a firm with a competitive advantage as they expand to international markets. However, international retailers seeking to maximise company performance must be able to manage the knowledge transfer of technical expertise (Haspeslagh and Jemison 1991) to suppliers and employees. 
Because technical expertise is developed over time, these retailers must invest in long-term development of such expertise in order to be well-positioned to transfer that knowledge as part of an international expansion strategy during a recession. When international retailers are in the situation of an economic crisis, the transfer of this expertise may be particularly crucial, because recessions may compress profit margins, increase competition and create unique. Whether the economic downturn is in the home country and creating a push factor, or in a potential host country and creating a pull factor, either dynamic can entice the firm to expand into foreign markets during the crisis. In either a push or a pull environment, international retailers may use their technical expertise in transferring knowledge between organisations. The financial success of an international expansion in these circumstances may depend on the success of such transfer.

As mentioned above, technical expertise can provide an important competitive advantage in international expansion. Explaining the importance of resources to companies, Hunt's (1997) resource-advantage (RA) theory maintains that competitive behaviour by companies constitutes "a process of competitive firm behaviour that emphasises the importance of market segments and resources". According to RA theory, firms' resources may be either tangible or intangible. Tangible resources include those that are financial (e.g., cash, access to financial market), physical (e.g., plants, raw materials, equipment) and legal (e.g., trademarks, license), while intangible resources include managerial (e.g., skills, competencies, control of organisation), informational (e.g., knowledge about technology, consumers and competitors) and relational (e.g., relationships with business partners and consumers; Hunt, 1997). Applying RA theory to international retailers' competitive behaviour and understanding their technical expertise as a type of resource suggests that technical expertise, as one of our suggested three modes of knowledge transfer, could play a role in international expansion during an economic crisis.

The development of technical expertise, such as an effective system for sharing information (knowledge transfer) between organisations, whether they are separate vendors or separate firms, requires a firm's long-term investment. Technical expertise that has been developed in the firm's original domestic market could be a critical form of tacit knowledge for international expansion efforts. Thus, the better equipped a firm is to engage knowledge transfer of its technical expertise, as developed over the long term from its domestic market, the stronger the firm's financial performance may be in international expansion during an economic downturn. Examples of retailers' cases in the next section amplify this point.

\subsection{Financial performance is influenced by knowledge transfer via technical expertise}

\subsubsection{Best buy vs. metro group}

The cases of Best Buy and Metro Group provide an illustrative comparison of when investment in technical expertise may succeed or fail as a strategy for knowledge transfer. During the economic crisis that began in 2007, Best Buy failed in its expansion from the USA to China due to its inadequate data-sharing system, while Metro Group succeeded in its expansion from Germany to China (against Best Buy) and from Germany to Russia by engaging in more effective technical expertise-based knowledge transfer. 
Best Buy, an American electronics retailer with stores in all 50 states, Washington DC, Puerto Rico, Canada and Mexico, provides an example of insufficient knowledge-sharing with partners, specifically suppliers, during the US's 2007 financial crisis. Best Buy failed to implement a reliable, accurate network system for the exchange of real-time, in-sync data, which became problematic since the 2007 recession made consumer spending unpredictable. Best Buy's electronics suppliers had to make their own decisions for the amount of electronics they should manufacture and they had difficulty making accurate purchasing decisions (Dvorak, 2009). Suppliers decreased their orders to accommodate a perceived decrease in demand, but as Best Buy experienced a higher demand than anticipated, the suppliers could not fulfil Best Buy's needs (Roberti, 2009). Both parties lost sales. Had Best Buy engaged in more effective knowledge transfer (e.g., exchange of accurate, real-time, in-sync data from the network system) with its suppliers, it would have been able to better predict the consumer demand for electronic products and manage the supply accordingly. Instead, their net income in the domestic market decreased by $77 \%$ for the three months following November 2008 (Dvorak, 2009).

Best Buy's woes followed it into the international electronic retailing market. With the U.S. recession, Best Buy began to seek profitable foreign markets and they expanded to China and the EU. In 2011, Best Buy decided to withdraw its business from China (Business Bloomberg News, 2011), with the final withdrawal occurring in 2014 while its competitor, German retailer Saturn Media, another international consumer electronics retailer owned by Metro Group, was just beginning to prosper in the Chinese market. Then, in 2013, during the European Sovereign Debt Crisis, Best Buy left Europe by selling its 50\% interest there to Carphone Warehouse Group. Overall, from 2013 to 2014, Best Buy's international revenue fell 8.4\% (Burkitt, 2014), continuing the pattern of decline relative to international consumer electronics competitors such as Germany's Saturn Media. Best Buy thus presents an example of unsuccessful knowledge transfer, with its technical expertise gained in its domestic market practice failing to maintain a competitive advantage as it expanded internationally during a recession (Larsson and Finkelstein, 1999). Because technical expertise develops over time (Barney, 1991; Szulanski, 1996) and cannot be rushed, uncertain situations like the US recession and European Sovereign Debt Crisis can be much better weathered by firms that have already been making long-term investments in their development of technical expertise against heightened competition. Best Buy hadn't been investing technical expertise like real-time data sharing over the long-term. Best Buy's insufficient knowledge transfer relative to its competitors in a time of excessive need harmed not only its own profits, but also those of the electronic suppliers with whom it had allied itself.

By contrast to Best Buy, the case of Metro Group provides an example of firm spending years to develop technical expertise from its domestic market before using that expertise to expand internationally. Long before Metro Group faced Best Buy in the heightened competition of the international market during the US recession and the European Sovereign Debt Crisis, Metro Group had been cultivating its inventory-tracking technology. Metro Group is a German retailer group comprising several divisions such as the consumer electronics retailer Saturn Media and the grocery retailer Cash and Carry Food and is one of the biggest players in the EU. Metro developed the technical expertise to share inventory information with suppliers in real time through technological networks (Retail Technology, 2008). Its technical expertise was developed over time (Barney, 1991; Szulanski, 1996) within its domestic market, Germany. The firm used a 
MicroStrategy-based system to perform online assessment of selected data from the Metro Data Warehouse (MicroStrategy, 2009; Retail Technology, 2008). These data and analyses could then be shared across internal business units as well as with external partners (Retail Technology, 2008). The system enabled Metro to improve inventory availability on the shelves by forecasting out-of-stock items, monitoring consumer behaviour and formulating strategies based on analysis of new product performance, promotions and advertising campaigns with suppliers (MicroStrategy, 2009). Updated data could be shared across all sales divisions on a daily basis. Metro's technical expertise enabled it to transfer knowledge to its allies, making for smoother, more efficient performance and giving it a competitive advantage. Knowledge transfer between partners can create value, which can improve a firm's competitive position and performance (Haspeslagh and Jemison 1991), as the case of Metro Group demonstrates.

In its international expansion, Metro Group drew on the technical expertise that it had developed over time to improve its internal capability and it extended that expertise to other markets. In the wake of the 2007 US recession and European Sovereign Debt Crisis, which heightened competition globally, Metro was able to expand into Russia by using the global data synchronisation network (GDSN) to great effect in managing inventory with suppliers (e.g., Kraft, Nestlé and Procter and Gamble) (FierceRetail, 2008; Russia is Next in the Move to Synchronise Data, 2009). In essence, Metro applied its technical knowledge experience of MicroStrategy Web to the use of GDSN. Thus, Metro's technological expertise, specifically its technological network system for realtime, in-sync knowledge-sharing, lessened the risk of its expansion into Russia. Metro Group later went on to expand into other international markets, synchronising European GDSN data in Germany, Poland, the United Kingdom, Denmark and Hungary (FierceRetail, 2008). In 2010, Metro's Media-Saturn division, which produces consumer electronics, then began opening stores in China (Ambre, 2010), where it performed competitively against firms such as Best Buy. Overall, Metro's knowledge and technical expertise across all its Metro Group divisions enabled it to outperform both domestic and international competitors during two major economic downturns. Just as social capital can enhance a firm's performance by providing the benefits of social networks (Pennings et al., 1998), Metro used its technical expertise to attract partners (suppliers), with whom it engaged in synergistic performance.

\subsubsection{Tesco's successful expansion from the UK to Korea via unique CRM strategy}

A third example of knowledge-sharing using technical expertise to facilitate knowledge transfer in economic crises is British supermarket giant Tesco, whose successful CRM information processes made the company a competitive retailer in its domestic market in the UK and later in the international market. This was especially the case in Korea, where the 1997 Asian recession created a pull environment for foreign companies. Tesco first established its CRM database system in its domestic market and there, maximised profits through database marketing (Clubcard membership; Rowley, 2005). Tesco then drew on this technical expertise when expanding into the Korean market during the Asian Financial Crisis of 1997. The firm shared its CRM knowledge with its joint venture partner, the grocery chain Homeplus, a division of Samsung Corporation, to gain Korean market knowledge (Sung and Sternquist, 2010). The technical expertise, in the form of data-driven statistical and technical analysis of CRM, provided the joint venture of Tesco 
and Samsung Homeplus with competitive advantages in the Korean market. Competitors such as the American retailer Wal-Mart and the French retailer Carrefour had also come to Korea during the Asian Financial Crisis, but failed to gain market share against Tesco in Korea. The case of Tesco's expansion to Korea once again illustrates the returns that can be brought about through knowledge transfer (Capron, 1999; Capron et al., 1998; Capron and Pistre, 2002) using technical expertise and alliance strategies.

\subsubsection{Carrefour's successful expansion from France to the European Union through alliance with IBM}

As of 2015, French grocery retailer Carrefour controlled 1,481 hypermarkets (or 'superstores') worldwide, according to its annual report of that year (Carrefour, 2015). Like many other retailing firms, Carrefour's international ventures suffered from the European Sovereign Debt Crisis (Alessi and McBride, 2015). In 2011, Carrefour's sales in Europe decreased by $3.4 \%$, with a $5.5 \%$ drop in Italy and $2.2 \%$ in Spain (Carrefour, 2011). Similarly, in 2012, net sales outside of France decreased by $2.7 \%$ (Carrefour, 2012). After another, smaller decrease in sales in 2014, Carrefour's sales in these markets grew by $2.8 \%$ in 2015 , signalling financial recovery. The retailing powerhouse finally reinvigorated its presence in Europe by focusing on its strategic, centralised company vision and conducting rigorous analysis on how to delegate resources effectively (Carrefour, 2015). The key to Carrefour's transfer of technical expertise amidst financial hardship was its partnership with International Business Machines (IBM). In 2009, just one year before the European Sovereign Debt Crisis began, Carrefour had made a five-year deal with IBM, the world's leading technology company, to create for them a customised management system that would be flexible and responsive (Berman et al., 2010). Carrefour's goal in partnering with IBM was to improve its customer relationships and marketing effectiveness, as well as ascertain a deeper analysis of consumption trends (IBM, 2009). Via this strategy of alliance with IBM, Carrefour was able to embed the proprietary technology, representing the company's technical expertise, within its own management systems, a form of knowledge transfer that supported the grocery retailer's effective operation throughout the European Sovereign Debt Crisis. Carrefour's agreement with IBM and the application of its hardware, software and consulting services, ultimately increased Carrefour's technical expertise, enabling knowledge transfer that would support its expansion throughout the European Union. By 2015, Carrefour's new management systems for marketing and consumer trend analysis, created through its alliance with IBM, enabled the grocery retailer to increase sales by $2.8 \%$.

\subsubsection{Zara's successful expansion from Spain to the European Union using supply chain management technology}

Whereas Carrefour's case illustrates how technology can be used to get in touch with customers and make an entire operation more synergistic, Zara's case exemplifies how technological solutions can completely transform a company's supply chain management system, facilitating knowledge transfer (e.g., inventory information) between divisions. Zara is an international retail brand whose parent company, Inditex, is headquartered in northern Spain. As of 2014, Inditex had 6,500 stores in 88 countries, with Zara being its largest fast fashion brand (Ruddick, 2014). The New York Times Magazine reported in 
2012 that Inditex had expanded to 110,000 employees in 2011 from 80,000 in 2007, even as Spain had been suffering from the European Debt Crisis (Hansen, 2012). Over the five years from 2007 to 2011, Inditex had flourished: its sales grew from 9.4 billion Euros to 13.8 and Zara contributed greatly to this growth (Hansen, 2012). One of the keys to Zara's success was its supply chain management, particularly its technological systems for filling inventory (Lu, 2014). On a daily basis, thousands of Zara stores communicated with headquarters about which products were selling and these trend reports were used to determine which new products to ship out to the stores. By fulfilling customers' desires as they occurred and by cycling new products through approximately every eleven days, Zara maintained a competitive advantage in its responsiveness to the market. Zara's strategy of allowing their customers to dictate which products would be supplied made it a top-performing international retailer. Moreover, Zara's continual product research enabled it to enter new markets relatively easily (Hansen, 2012). Zara's efficient supply chain management system eliminated waste, including unnecessary inventory transportation and holding costs. Cutting such expenses is essential in times when sales numbers are hurting.

Proposition 1 The better-equipped a firm is to engage in effective knowledge transfer facilitated by technical expertise, as developed over the long term in its domestic market, the stronger the firm's financial performance in international expansion during an economic downturn.

\subsection{Firm financial performance is influenced by knowledge transfer from local partners via joint venture alliance strategies}

A second strategy that we consider as a potential mode of knowledge transfer for firms that are internationally expanding during recessions is alliance-building. Firms can form international alliances, defined as temporary arrangements between two companies from different countries for the purpose of sharing resources and benefits (Spekman et al., 2000), in order to obtain and transfer new or existing knowledge (Björkman et al., 2004, 2007). For a firm expanding into an international market, forming an alliance with a local partner can provide a competitive advantage over rival entrants to that new market (Pennings and Lee, 1999). One of the main reasons firms choose alliances is the desire to gain local knowledge (Beamish, 1989; Zhao and Zhu, 1998). Johansson and Vahlne's (1997) internationalisation process model identifies three types of local knowledge that are important for international retailers: knowledge of the foreign market; knowledge about marketing and consumer characteristics; and capabilities and resources for internationalisation. A firm's foreign market knowledge should encompass competitors, the government's relationship to business and a country's institutional values and structure (Jonsson and Elg, 2006). Moreover, according to Vida et al. (2000), as well as Dawson (2003) and Palmer (2006), extended knowledge for retail internationalisation has three components:

1 market knowledge, i.e., of the customers, competitors, suppliers and legal issues

2 internationalisation knowledge, i.e., of expansion and entry into the foreign market

3 corporate knowledge about the organisational goals, strategies, cultures and know-how. 
The link between international alliance formation and knowledge transfer lies in the fact that firms' ability to access or transfer tacit knowledge depends on their use of alliance strategies (Karim and Mitchell 2000). Forming alliances with local partners is particularly useful for acquiring the local or tacit market knowledge, which pertains to the target market. Tacit knowledge is by definition difficult to teach. Thus, alliance strategies that fit the needs of a particular foreign market are essential to the use and communication of tacit knowledge in international businesses. In this paper, we are specifically interested in the joint venture alliance structure, which involves the establishment of 'a new separate or independent entity' by two or more firms (Groot and Merchant, 2000). The main difference between a joint venture and other types of relationships, such as acquisitions, is the 'shared ownership and control between firms' (Geringer, 1998). Joint venture alliances are understood by both parties from the outset as temporary arrangements; the pre-planned dissolution of joint ventures is a phenomenon explained by Marriage and Divorce Theory (Barham et al., 2009; Sung and Sternquist, 2011). For international retailers, the formation of temporary alliances is a common strategy in international retailing expansion, intended to aid the expanding retailer in its entry to the new market and aid the partner firm in profit. These alliances are referred to as international joint ventures (IJV).

The salience of IJV as a means of knowledge transfer for retailers is illuminated by RA theory as described above. RA theory (Hunt, 1997) suggests that the resources firms use to enter foreign markets, such as knowledge about foreign consumers and competitors, are critical to their competitiveness. International retailers can use partnership strategies such as alliances to acquire knowledge about foreign markets through other companies in the target market. Previous studies show that forming an alliance with a local firm can provide the retailer that seeks to expand with a vehicle for knowledge transfer. Exchanging knowledge with the local partner firm enables the expanding firm to better understand local consumers' needs and thus can improve consumer satisfaction (Chen, 2004). For this reason, the formation of partnerships through alliance or acquisition strategies could be an appropriate vehicle for retailers seeking expansion in a foreign market. The specific partnership strategy that a firm uses in transferring knowledge between organisations depends on the types of knowledge that the firm needs to transfer (Chen 2004).

When a firm is entering a foreign market in a different cultural bloc during an economic crisis, the more quickly the firm allies with a local partner, the more effectively it can improve its financial performance internationally through knowledge transfer. Two examples of retailers who formed such local alliances are provided below. The British retailer Tesco and the Spanish retailer Zara both entered into the unfamiliar cultural bloc of Asia (Korea and Japan) as the continent was undergoing economic recession. In doing so, both European firms chose to form IJV alliances with local partners to achieve the knowledge transfer that would enable them to gain knowledge of their host countries. Specifically, the firms engaged in knowledge transfer with local allies in order to understand the host country's local market and consumers, positioning the firms to take advantage of the 'pull' of an economically recessed host country environment that was attempting to lure foreign investment at the time. In both of these cases, the alliances that firms formed were intended to bridge the cultural divide between the home country and the host country. 


\subsubsection{Tesco's successful expansion into Korea through IJV alliance with Samsung Homeplus}

When the British Retailer Tesco sought to enter the Korean market during the Asian Financial Crisis of 1997, 'pulled' by a recession environment that favoured foreign companies, it began by forming a business alliance with Samsung Homeplus, a division of Samsung Corporation, which at the time was one of Korea's strongest grocery retailers. Like most businesses looking to expand, Tesco must have first evaluated the costs and benefits of expansion and local partnership (Brouthers, 2002; Erramilli and Rao, 1993). At the time, the Korean government was just starting to open the retail market to foreign retailers in an effort to boost the Korean economy (Suh and Howard, 2009). The Korean market, which included firms like Samsung Corporation, was suffering nationally due to the Asian Financial Crisis and the Korean government was becoming strategically interested in foreign investment. As internationalisation theory explains, the accumulation of local knowledge depends on gaining direct experience in a given market (Johansson and Vahlne, 1977, 1990). However, Tesco was able to gain local knowledge through alliance with Samsung, as the latter transferred the knowledge it had accumulated in the Korean market. In this way, Tesco engaged in the second mode of knowledge transfer we investigate, alliance formation.

Tesco's choice to form an IJV as an alliance strategy was very critical to its successful international expansion. Tesco formed its IJV with Samsung before either of its main competitors, the American retailer Wal-Mart or the French retailer Carrefour, had entered the Korean market. This meant that while Wal-Mart and Carrefour were still familiarising themselves with their Korean customers, Tesco was already using Samsung's knowledge to succeed. Tesco had been quick to recognise that being from a completely different culture, or cultural bloc, than Korea, it would need to adjust its practices in order to be successful there. A cultural bloc is defined as a group of countries with major differences in culture (Ronen and Shenkar, 1985). For Tesco, the most efficient strategy to gain the necessary local knowledge to expand to a new cultural bloc (and do so more quickly than competitors such as Wal-Mart and Carrefour) was to find a local partner within the targeted cultural bloc. Tesco's competitive edge gave the expanding retailer the upper hand on the competition, which was especially important given the economic crisis that was underway.

Firms that expand into foreign markets in cultural blocs must resist reliance on non-local experience, instead acquiring knowledge from countries within the similar culture as the target market (Barkema et al., 1996). When Wal-Mart had entered the English-speaking Canadian market, which is culturally similar to the USA, it had made sense to apply the knowledge and routines of its own local technical expertise and tacit knowledge. However, when the firm entered into the Korean market, it did not have the benefit of relevant cultural knowledge (March et al., 1991). If Wal-Mart or Carrefour used its existing knowledge in the novel environment of Korea, it might find this knowledge to be inapplicable or even detrimental (Nadolska and Barkema, 2007). Meanwhile, Tesco's joint venture strategy enabled it to start understanding Korean customers' needs and wants, gain knowledge about their preferred shopping experiences and provide shopping environments they found preferable to Wal-Mart's low-cost environment (Sung and Sternquist, 2010). Based on its understanding of Korean customers and their preferences in shopping environments (Sung and Sternquist, 2010), Tesco even opened a complex at Jamsil, Seoul, Korea in 2007, that focused on art and 
well-being. The complex featured social centres (e.g., wine bar), art galleries, health facilities (e.g., sauna, golf practice area), technology service facilities and classes in language, cooking and other subjects (Kim, 2007).

Tesco's decision to quickly engage in a joint venture for rapid knowledge transfer with Samsung Homeplus enabled them to be very successful against competitors in the economic pull environment of the host country. Their use of local alliances as a mode of knowledge transfer led to strong performance and rapid expansion. Thus, knowledge transfer improved Tesco's competitive position and performance compared to Wal-Mart and Carrefour. Tesco's transactional cost in the IJV - money as well as the transfer of their own tacit knowledge and expertise - was ultimately compensated by their gains in knowledge about the Korean market. This knowledge enabled them to rapidly build a presence in Korea post-acquisition, rather than having to build from the ground up as Wal-Mart and Carrefour had had to do (King et al., 2004).

Ultimately, even though Tesco, Wal-Mart and Carrefour all entered the Korean market around the same time, Tesco came in with proven local knowledge from a partner, whereas its competitors had to develop their own local knowledge. Throughout the time that Wal-Mart and Carrefour were struggling to learn about their customers and their new market, Tesco could use the local knowledge to develop a foothold. This proved to be an essential competitive advantage. Overall, firms that wish to follow Tesco's example in expanding into a completely different cultural market or cultural bloc should consider using alliances with local firms to gain local knowledge. This mode of knowledge transfer in economic crisis enables faster adaptation to the local market than competitors in the attractive pull environment. In this way, the allied firm develops a competitive advantage over non-allied competitors and gives itself the best chance of thriving in the recession.

\subsubsection{Zara's successful expansion into Japan through IJV alliance with Bibi Group}

Another case of a retailer forming an IJV alliance to gain knowledge of a target market is the global fast fashion retailer Zara. Based in northern Spain, this international retail leader operates under the parent company Inditex (Hansen, 2012). In the late 1990s, Zara was in a period of aggressive expansion and it managed to successfully enter the Japanese market even as the country was experiencing economic shocks brought on by the 1997

Asian Financial Crisis. The effects of this recession included decreases in the value of stocks, a capital loss of $170 \%$ of the GDP in 1996, the widening of this gap in 1997 and 1998 and a fall in supply and demand among corporations (Research Bureau, Economic Planning Agency, 1998). Although it was during this downturn that Zara moved to Japan and although Japan was the first Asian country that the retailer had attempted to enter, the company was able to experience massive growth in this new cultural bloc by forging a joint venture with the Japanese firm Bigi Group (Yoshioka, 2015). Zara launched its 50-50 joint venture with Bigi Group in 1998 in order to take advantage of the Japanese firm's wide knowledge of the clothing and property sectors in Japan. That knowledge could be transferred to Zara via the two firms' joint venture.

As Zara entered the Japanese marketplace, it pursued a geocentric orientation, having learned during a period of cautious international expansion in the years 1989 to 1996 that an ethnocentric approach was less effective. A geocentric orientation involves adapting to the local marketplace, instead of imposing the domestic market's practices onto the new 
site. This orientation emphasised the application of knowledge gained from the joint venture. By 2009, Zara had procured full ownership of its storefronts in Japan (Lopez and Fan, 2009). To date, Zara continually communicates with all of its stores individually and customises orders to each particular fashion region. This flexibility and technological advantage has helped Zara adjust to the needs and wants of Japanese customers, notwithstanding the differences between the European and Asian cultural blocs. Overall, the case of Zara provides further evidence of the importance of allying with local retailers, as one possible mode of knowledge transfer that can be effective when entering a new cultural bloc during a financial crisis.

Proposition 2 The more effectively a firm engages in knowledge transfer via alliance-building in a cultural bloc, the greater its opportunity for financially successful international expansion during an economic crisis.

\subsection{Firm financial performance is influenced by knowledge transfer via focused allocation of resources toward acquisition}

A third knowledge transfer strategy that retailers may deploy when seeking to engage in international expansion during economic crisis is the focused allocation of firm resources. As alluded to in the previous section, Barney's (2001) RA theory suggests that a resource-based view of firms' behaviour can illuminate firms' decisions with respect to how they allocate their resources and suggests how these decisions impact firms' competitive advantage and performance. A resource-based view can help identify the resources at a firm's disposal that can be used or implemented in executing a business strategy. Two types of resources, as identified on Hunt's (1997) seven-category classification, are pertinent here: physical resources (e.g., plants, equipment) and informational resources (e.g., consumers, technology). Unlike strategic assets, these types of firm resources are treated as rare, valuable, not substitutable and not perfectly imitable (Barney, 1991). When a firm focuses on allocating its physical and informational resources with a view toward knowledge transfer, it can improve its chances of succeeding in international expansion during economic downturns.

Depending on the type of capacity-gaining knowledge that must be transferred, a retailer can choose to focus the firm's resource allocation on the acquisition of assets that will facilitate that knowledge transfer. An acquisition is distinct from an alliance in that it is a permanent arrangement in which the acquiring firm obtains full control over the acquired firm's resources. An acquisition may be preferable to an alliance in cases where tacit knowledge must be transferred, especially across cultural lines. For example, the Korean retailer Sungjoo's decision to acquire the German retailer MCM rather than using a typical 50/50 joint venture form in its executive decisions on business operations enabled the former to sidestep the difficulties of a high-level intercultural alliance. As Niederkofler (1991) has noted, an alliance structure can be strongly prone to conflict, especially when it is between firms based in different countries. Because the existing employees in one firm and the decision-makers in another firm might have difficulties in managing the intercultural partnership, an acquisition partnership strategy might be more effective than an alliance strategy (e.g., joint venture) for enabling tacit knowledge transfer.

To summarise, the pursuit of knowledge transfer via the focused allocation of firm resources that can facilitate that knowledge transfer can be expected to influence firms' 
financial performance in international expansion. Firms can allocate their resources toward specific acquisitions that cohere with the type or degree of knowledge (i.e., tacit versus codified) or resources (i.e., physical versus informational) that they need to transfer. The next two sections outline the cases of Sungjoo and Carrefour, two retailers that turned down several opportunities in order to focus their resource allocation on the acquisition of assets (firms and real estate, respectively), which supported their goal of transferring specific bodies of knowledge. By focusing their resources on strategic acquisitions, these firms improved their financial performance even as their competitors suffered from the economic downturn.

\subsubsection{Sungjoo group's successful acquisition of MCM to facilitate knowledge transfer via focused resource allocation}

The international luxury fashion retailer Sungjoo Group sells imported luxury apparel brands, mostly in Asia, Europe and the USA Sungjoo Group's case, specifically its acquisition of the German luxury handbag brand MCM, illustrates how an international retailer can manage its focused resources to obtain external knowledge and create value. When the 1997 Asian financial crisis began, the firm had in place an exclusive rights agreement to sell imported luxury brands such as Gucci, Yves Saint Laurent and Sonia Rykiel in Korea (Ramirez, 2010). However, the 1997 Asian financial crisis created a push environment, especially toward retailers in international business and brought high exchange rates for luxury imported goods. This made imported luxury items tremendously expensive for consumers in many East Asian countries. Sungjoo Group was threatened by the economic climate and felt extreme pressure to reform its organisation and find ways to maximise its resources. In response, Sungjoo Group gave up its exclusive importing of luxury brands and started to look for new opportunities in the push environment created by to the economic crisis. The challenges that were posed to Sungjoo Group in the economic recession in its home country of Korea, particularly the high exchange rates for importing luxury goods from foreign countries, created a 'push' that prompted the firm to seek expansion to the foreign EU market. In undertaking this expansion, the used an acquisition strategy to achieved knowledge transfer (i.e., gain knowledge of the EU cultural bloc and market) to focus one brand among several fashion brands. Specifically, the firm took over the German luxury handbag manufacturer MCM, from which it gained both physical and informational resources. Its physical resources included employees and factories and its informational resources included knowledge about manufacturing processes and European luxury fashion markets and consumers. Through its acquisition of MCM, Sungjoo was able to achieve the highest level of knowledge transfer and focus on one dedicated fashion brand, ensuring the firm gained the knowledge of the EU luxury industry that it needed to succeed in that market.

In order to make this acquisition of MCM, however, Sungjoo Group had to engage in a focused allocation of resources: they decided to give up some of their exclusive luxury brand rights in Korea in favour of pursuing aggressive international expansion into the fashion luxury industry with only a few dedicated brands. Sungjoo Group believed that this strategy would allow them to maximise revenue and minimise the cost of importing luxury brands, which had become incredibly expensive due to exchange rates that were unfavourable to Korean companies. When Sungjoo Group chose to focus its allocation of resources on buying the German luxury apparel brand MCM with the intent of rebranding MCM's existing products (History Sungjoo Group, 2017), the firm made a single-minded 
decision to give up all its other brands and restructure the company accordingly. Sungjoo Group's hope was that restructuring its organisation would enable it to survive and convert the financial crisis into a new opportunity for international expansion in the push environment from the home country. At the time of acquisition, MCM's bottom line had been suffering due to the rampant counterfeiting of their products (Ramirez, 2010) and its image as a luxury brand was failing. Sungjoo Group's decision to purchase this struggling brand was just one among several aggressive decisions they made about which resources to carry and which to give up as they dealt with the impact of the economic downturn. The Korean retailer went on to commit itself to acquiring even more assets in this risky market in order to maximise the profits of their knowledge transfer from MCM. Through their strategic acquisition alliance, Sungjoo Group eventually increased MCM's sales from $\$ 100$ million in 2005 to $\$ 250$ million as of 2009 (Ramirez, 2010). The focused allocation of firm resources to the acquisition of MCM put the retailer in a strong competitive position and greatly improved its performance. Crucially, the knowledge transfer that Sungjoo received from MCM made possible Sungjoo's successful rebranding. This case aligns with previous findings that knowledge transfer creates value and thereby improves firms' competitive position and performance (Haspeslagh and Jemison, 1991).

Sungjoo made a variety of strategic decisions about how to allocate both physical and informational resources. In acquiring MCM's physical resources, including its plant headquarters and manufacturing equipment, Sungjoo chose to keep the existing system intact in Germany rather than move it to Asia because the retailer valued MCM's existing employees, suppliers and relationships with European consumers. Sungjoo recognised that moving knowledge from Germany to Korea would be very difficult and that by keeping the physical resources intact, they could effectively facilitate tacit knowledge transfer (Karim and Mitchell, 2000). The retailer's choice paved the way for future expansion in Europe due to the particular characteristics of luxury fashion brands. By contrast, in deciding how to allocate its information resources (consumers), the retailer made a strategic choice not only to remain in the luxury fashion business in the European Union, but also to expand to Asia, even though the Asian economy was risky during the Asian financial crisis. Their success in doing so depended on their deep understanding of Asian consumers' luxury purchasing behaviour. According to Sternquist et al. (2004), Asian consumers such as Korean and Chinese shoppers love luxury brands and understand their high prices as a cue of high quality. In addition, because of their collectivist culture, they like to gain or reinforce their social status through purchases of high-priced goods. Sungjoo further understood that, for Asian consumers as well as for the new customers they were targeting in the EU, luxury fashion brands must be "Made in [a European Country]" in order to be highly valued. Knowing this, Sungjoo Group aggressively pursued a strategy to acquire the German luxury handbag brand, MCM. Had Sungjoo merely used an alliance strategy such as a joint venture, rather than focusing its resource allocation on acquisition, it would have remained limited to its existing market of Asian customers. Whereas the retailer understood its Asian consumers based on past experiences and previous data, it was able to understand the European market to which it was expanding by gleaning external knowledge about consumers through its acquisition of MCM. The retailer's international expansion to European countries was based on this acquisition strategy from the beginning.

Sungjoo, who sought to internationalise in the luxury fashion industry, might have found that manufacturing the products, maintaining the image of the brand and gaining 
the information they needed about foreign markets was not easy or codifiable. The type of knowledge needed should drive the strategy (Chen, 2004) or strategies they adopt. In the case of Sungjoo, the focused allocation of resources for acquisition was effective because the knowledge to be transferred was tacit. Knowledge transfer between companies is particularly difficult when the production knowledge is tacit (Grant, 1996), but firms that have a better understanding of new knowledge may have a higher level of absorptive capacity (Tsai, 2001; Makhija and Ganesh, 1997). In cases of tacit knowledge transfer, equity-based alliances between business partners can support the transfer better than contract-based alliances, because the tacit knowledge is embedded within the organisation (Kogut, 1998). Tacit knowledge transfer requires a high level of absorptive capabilities of knowledge transfer between organisations (Kogut, 1998).

Sungjoo's focused decision-making enabled it to make a sound investment when it gave up exclusive rights to several famous luxury brands in order to focus on one dedicated brand, a choice that transformed the company. In the midst of financial crisis, these choices made this retailer bigger, better and more competitive than ever. In order to reform and gain competitive position and advantage, the retailer made decisions that reflected an interest in first maximising knowledge transfer via the focused allocation of frim resources before being concerned with maximising profit. This can be a sound strategy for international retailers who wish to expand and thrive during difficult economic times.

\subsubsection{Carrefour's successful expansion to the EU via resource allocation mode of knowledge transfer}

Similar to Sungjoo's acquisition strategy in relation to MCM, the French retailer Carrefour responded to economic recession by enacting a single-minded strategy to allocate its resources toward the acquisition of real assets (Reuter, 2013) that supported the firm's knowledge transfer. After the European Sovereign Debt Crisis broke out in 2011, Carrefour's sales fell outside its domestic market; the firm saw a 3.4\% decrease in sales in Europe in 2011 and a 2.7\% decrease in Europe in 2012 (Carrefour, 2011, 2012). Yet, from 2012 onward, Carrefour began to practice a single-minded focus on EU expansion, shifting focus away from non-EU markets (Alessi and McBride, 2015). As real estate prices in the EU market were suffering, these depressed prices acted as a pull factor, prompting Carrefour to invest its resources in purchasing hundreds of shopping malls across the European Union, especially in areas of the EU where the economic suffering was most severe. Even as Carrefour suffered from the European Sovereign Debt Crisis, facing steady losses and the threat of losing market share, the firm narrowed its focus to its most successful territories and delegated more decision-making authority to local stores in the EU (Daneshkhu, 2012). The French retailer Carrefour made strategic decisions about how to allocate its financial resources and which physical resources to purchase to ensure smooth knowledge transfer about European markets and consumers.

This focusing of resource allocation on European countries strengthened as Carrefour made extensive strategic purchases over the next two years, even as European firms were still suffering under the European Sovereign Debt Crisis. In 2013, Carrefour bought 127 shopping malls in France, Spain and Italy from Klepierre, a real estate group (Vidalon, 2013) and in 2014, it bought 53 Billa outlets in Italy (Dauer, 2014). After purchasing the shopping malls from Klepierre, Carrefour formed Carmila, a wholly owned subsidiary company solely devoted to creating value for Carrefour's customers in France, Spain and 
Italy (Carrefour, 2014). Carrefour's strategy for surviving the economic crisis in the pull environment (e.g., the low prices of real estate across the EU) was to focus single-mindedly on their most successful territory, the European Union, instead of other international markets. In this way, Carrefour was able to allocate its investment toward obtaining resources such as shopping malls. As RA theory explains, the retailer effectively managed its informational (e.g., consumers), physical (e.g., shopping malls) and managerial (e.g., competencies and control) resources. Carrefour's decision to pour vast resources into purchasing EU real estate over any other investment was a direct response to the recession, which made such purchases favourable in the pull environment. By following this strategy, Carrefour was able to expand quickly during the 2011 European Sovereign Debt Crisis, while making the strategic decision to delay any further investment or expansion in other areas against other competitors. The French retailer's success in the EU territory shows that it knows European consumers better than consumers in other cultural blocs, such as Asia, where its international expansion during the 1997 Asian Financial Crisis was unsuccessful. The knowledge transfer that supported the firm's expansion in the EU was rapid and enabled Carrefour to take advantage of the opportunity during this particular period of the European Sovereign Debt Crisis. The company succeeded due to its speedy transfer of knowledge, namely market information from the shopping malls it purchased.

Carrefour's decisions relative to its competitors can be interpreted in light of game theory. According to Osborne (2003), game theory can explain firms' conscious, goal-oriented decision-making, including their choices, moves, strategies and the results of their business operations (Shubik, 1972). Unlike real option theory, which maintains that firms may delay investment during periods of uncertainty, game theory helps explain why a firm might find it more optimal to move ahead with an investment opportunity even in an environment of economic downturn (Kulatilaka and Perotti, 1998). Given the high uncertainty of a recession environment, firms are well advised to consider both perspectives in their decision-making processes (Kulatilaka and Perotti, 1998). Moreover, as Huang and Sternquist (2007) have pointed out, the uncertainty of the environment should also inspire firms entering international markets to also carefully consider the timing and mode of their entry, as well as the locations for their retail outlets. Depending on the amount and quality of information a firm possesses about the target retail market, retailers might choose to open or delay their investment decisions (Ashuri et al., 2008). In applying game theory to Carrefour's rigorous, successful international expansion within the relatively familiar EU markets during the European Sovereign Debt Crisis, as compared to its unsuccessful international expansion into the unfamiliar cultural bloc of Asia during the Asian Financial Crisis, it becomes clear that the French firm Carrefour had greater success with its EU expansion. The French retailer took the opportunity to expand its business quickly within similar cultures, accomplishing its expansion by aggressively purchasing real estate such as shopping malls across the EU at a time when most firms were reducing their investment. Throughout 2012, Carrefour rapidly invested its financial resources in real estate in order to expand internationally without forming any alliances in the culturally similar European market. Carrefour's knowledgeability about European markets and its quick action enabled it to invest in opening more stores during the European Sovereign Debt Crisis. The firm was far more successful and more quickly, than it had been in entering Korea in an earlier period of economic uncertainty, the 1997 Asian financial crisis. 
These two case studies, Sungjoo's takeover of the MCM brand and Carrefour's takeover of the shopping malls within the European Union, reflect the advantages of using a knowledge transfer strategy via single-minded or focused allocation of firm recourses - whether the acquisition of a competitor or the acquisition (purchase) of real estate - for their financial performance. Accordingly, we propose:

Proposition 3: The greater a firm's investment in the focused allocation of firm resources toward the goal of knowledge transfer, the stronger the firm's financial performance in international expansion during economic crisis.

\section{Research discussions}

Based on several case studies of successful and unsuccessful international expansion during economic crisis, we propose three modes of knowledge transfer that firms can deploy to potentially inform their success in such efforts:

1 long-term development of technical expertise beyond the domestic market

2 alliances with local partners in the target market, with whom the firm can engage in knowledge transfer across cultural blocs

3 focused allocation of firm resources for knowledge transfer.

These three propositions are based on six cases of international retailers that attempted to expand during the Asian financial crisis of 1997, the US recession of 2007 and the European Sovereign Debt crisis of 2009. Based on our case studies, there is a clear link between, on the one hand, a firm's success (or lack of success) in using knowledge transfer in international expansion and on the other hand, the three modes of knowledge transfer we have identified: investment in technical expertise, alliance-building and focused allocation of resources.

Proposition 1 states that the better equipped a firm is to engage in effective knowledge transfer via its long-term investment in developing technical expertise in its domestic market, the stronger the firm's financial performance may be in international expansion during an economic downturn. Indeed, the greater a firm's long-term investment in technical expertise in its domestic market prior to the economic downturn, the better equipped it is to engage in the sort of effective knowledge transfer during the downturn that contributes to financially successful international expansion in these conditions. This finding implies that in order for retailers to be poised to overcome the challenges of a downturn, whether the recession is in the host or home country, it may be helpful to have been investing in the development of technical expertise, such as information systems, over the long term.

Proposition 2 states that during economic crisis, when a firm is entering a foreign market, the more effectively a firm engages in knowledge transfer via an alliance-building with a local partner, especially in the target cultural bloc, the greater its opportunity may be for financially successful international expansion. Our investigation of international retailers' attempts at expansion during economic crises reveals that such an alliance-building strategy can enable firms to convert troubling times into opportunities for growth. In some cases of international expansion, the firms were expanding into entirely new cultural blocs, so one might anticipate slow performance in 
the short term. However, our cases show that when firms gain immediate access to local knowledge through forming alliances, especially in cases where the firm is acting under the pull factor of an economic recession in the host country, the firm gains a foothold in the market much more quickly than firms that do not form such alliances. Thus, this mode of knowledge transfer is particularly advisable for a firm experiencing a pull into a foreign market in economic crises.

Proposition 3 states that during economic crisis, international retailers can better facilitate expansion, translating to improved financial performance, if they make a focused or single-minded decision to restructure their allocation of resources for knowledge transfer in the course of international expansion. Based on our cases, we suggest that in firms' international operation strategies, making single-minded decisions (e.g., to focus on one brand in one territory or region) during economic crises enables firms to use their resources more effectively toward the goal of knowledge transfer. This focused resource use can then contribute to firms' international expansion achieving greater financial performance.

One of the key insights from our cases is that the effectiveness of various strategies around knowledge transfer depends on the degree of difference between the cultural blocs of the firm's home country and the host country. When a retailer was expanding into a cultural bloc that was very different from its own, it often used alliance strategies for knowledge transfer to achieve a competitive advantage, forming temporary partnerships with local firms. Recognising that different cultures have different styles of consumers and management, firms sought local alliances that could aid the firm in understanding not only the consumers, but also the employees in its target market. Being able to quickly establish oneself using a local partner is especially valuable when entering into a foreign market, as the firm usually must compete against other international retailers as well as established local brands (King et al., 2004). This is particularly true when the host country is experiencing financial crisis, creating a pull environment that attracts many other firms as competitors. By contrast, when retailers were entering markets in similar cultures or with similar market characteristics, they tended to quickly expand or adjust markets as soon as an opportunity came along. Rather than forming local alliances, they tended to acquire companies or real estate in the target market in order to gain informational resources quickly for their international expansion. For example, in the case of the retailer Carrefour, it could quickly expand internationally in the EU against competitors, not just despite but because of the recession, by identifying the opportunity and rapidly acquiring real estate in the target markets, where prices were depressed due to the economic crisis. The firm effectively transferred its pre-existing, similar market knowledge by allocating resources as an investment. As a result, it successfully increased its profits relative to competitors in the course of its rapid international expansion. These findings contribute to researchers' understanding of the strategies that international retailers use for knowledge transfer as they work to expand and improve performance during periods of financial crisis.

This study fills a gap in the understanding of how firms' investment in technical expertise, alliance-building and resource allocation can be effective modes of knowledge transfer that facilitate international expansion in economic crises. These findings are very much in line with previous thought about the importance of knowledge transfer and value creation for firms' competitive position and performance (Haspeslagh and Jemison, 1991). The current study is the first to explore these three modes of knowledge transfer in the context of international expansion during times of economic crises, building on 
previous findings regarding the relationship between knowledge transfer and firms' performance. The fact that these case studies all highlight the importance of external knowledge sourcing in efforts to grow during economic downturns suggests that knowledge transfer is even more valuable than had previously been thought. This importance must be due in no small part to the level of competition for survival that takes place during economic downturn.

Overall, these findings suggest that managers in international retail firms undertaking international expansion to overcome the challenges of economic recession, whether being pushed by a recession in the home country or pulled by a recession in the host country, would be well advised to stick close to their central strategic decision to expand and strategically engage in knowledge transfer during this process. Several modes of knowledge transfer are available to international retailers seeking to execute such expansions in economic crises. First, the development of technical expertise, which can then be the subject or means of knowledge transfer, can provide a competitive advantage in the heightened competition created by an economic crisis. Second, the pursuit and consolidation of strategic international alliances with local partners in the target cultural bloc is crucial for efficient transfer of knowledge, particularly when the target market is a pull environment (i.e., in recession), which favours foreign companies. Acquiring local knowledge is the most effective means of growth in new markets (Goerzen and Makino, 2007). Third, although internationalisation theory suggests that firms' investment of resources should be gradual, we find knowledge transfer theory to be more applicable; specifically, our cases suggest that the focused allocation of firm resources is effective in the restrained situations caused by economic crises, where firms must operate with heightened efficiency. The lessons learned in the exploration of these case studies suggest that firms can apply these strategies to benefit within other economic downturns, whether in a host country or the retailer's home country. Retailers may effectively respond to either push or pull environments, overcoming the challenges associated with economic downturns.

\subsection{Limitations and directions for future research}

Any successful international expansion involves many complex factors. In this paper, we sought to point out the major factors in knowledge transfer strategies that may help explain why expansions fail or succeed during economic downturns. While our focus was on knowledge transfer and specifically on three forms or modes of knowledge transfer, researchers and international retailers should not ignore the other factors that might be in play or the many possible strategies that might be successfully implemented. Moreover, while we focused on the firm resources delineated by RAs theory, namely informational and physical resources, future research might draw on examples from other types of resources for effective knowledge transfer that we have not mentioned, such as Hunt's (1997) managerial resources (e.g., skills of management, competencies and controls of organisation) and relational resources (e.g., relationships with competitors, suppliers and customers), especially in operating international retail businesses. For example, international retailers' use of social media and engagement strategies might help them identify needs in the foreign market. These strategies require language competencies in the target market rather than consumer information from foreign partners. Future research that explores what other factors could influence (as antecedents) retailers' strategic 
decisions on firms' financial performance might further inform firms' strategies to improve their international performance, particularly in conditions of economic downturn. On the other hand, future research could also explore instances where the international retailers in our study expanded during solid economic times; this would allow us to compare how these firms expanded in different economic climates and assess the interplay between economic climate and firms' strategic decisions.

Another area for future research is to explore what conditions are not conducive to the use of the three specific modes of knowledge transfer we have focused on (technical expertise, alliance-building and resource allocation). When are these strategies least effective or easily implemented in cases of international expansion during economic downturn, as compared to other possible modes of knowledge transfer? In other words, although we have recommended that firms use their technical expertise, alliances and resources as effective tools for transferring knowledge for international expansion, especially during economic downturns, some of these strategies may not work, or be as easily implemented, in all cases. In future research, it would be interesting to investigate other cases where these tools may not have been effective and consider why this is so and what other strategies work better in those cases. Moreover, in the unsuccessful case we studied, Best Buy, it would be illuminating to explore what other factors may have been at play in its failure. In our observations on Best Buy's use of knowledge transfer, we focused mainly on this retailer's use of technology, specifically their information system linking them with their suppliers. We paid attention to their systematic in-sync information system as a form of technical expertise, which they used for managing their supply chain with their suppliers. However, there might be other reasons for their failure during the economic downturn, beyond the problems with technical expertise. As mentioned before, Best Buy might have had problems in their relationships with suppliers and consumers that would have affected their financial performance in the international market, even without the problems with their knowledge transfer involving technological innovations.

Finally, future researchers might use the propositions derived from our case studies as a basis to conduct empirical research, both for the validation of these propositions and for the exploration of other factors and relationships beyond those we have considered here. Indeed, our paper is limited by our reliance on publically available information for our case studies and it is possible that there is internal information, inaccessible to us at this time, that is important to the story of firms' international expansion during economic recession. Future empirical studies might be conducted by gaining the cooperation of relevant international retailers who are willing to provide the researchers with information about their firms' financial performance during crises as well as information on the strategies the firms employed during those times. Such empirical research will be essential to deepening our understanding of how firms can thrive within the challenges and constraints of an economic downturn. 


\section{References}

Alessi, K.J.C. and McBride, J. (2015) The Eurozone in Crisis, 11 February [online] http://www.cfr.org/eu/eurozone-crisis/p22055 (accessed 1 November 2016).

Ambre, P. (2010) Metro Group Media-Saturn to Launch First Store in China, 4 October, Retail digital (global portal for retailers) website [online] http://www.retaildigital.com/sectors/electricals/metro-group-media-saturn-launch-first-store-china (accessed 30 March 2011).

Ashuri, B., Rouse, W.B. and Bodner, D. (2008) 'A real-options approach to modelling investments in competitive, dynamic retail markets', Proceedings of the 41st Annual in Hawaii International Conference on System Sciences, IEEE, January, pp.93-93.

Bacchetta, P. and Gerlach, S. (1997) 'Consumption and credit constraints: international evidence', Journal of Monetary Economics, Vol. 40, No. 2, pp.207-238.

Barham, V., Devlin, R. and Yang, J. (2009) 'A theory of rational marriage and divorce', European Economic Review, Vol. 53, No. 1, pp.93-106.

Barkema, H.G., Bell, J.H. and Pennings, J.M. (1996) 'Foreign entry, cultural barriers and learning', Strategic Management Journal, February, Vol. 1, pp.151-166.

Barney, J.B. (1991) 'Firm resources and sustained competitive advantage', Journal of Management, Vol. 17, No. 1, pp.99-120.

Barney, J.B. (2001) 'Resource-based theories of competitive advantage: a ten-year retrospective on the resource-based view', Journal of Management, Vol. 27, No. 6, pp.643-650.

Beamish P.W. (1989) Multinational Joint Ventures in Developing Countries, Routledge, London/New York.

Berman, S.J., Richard, C. and Bell, R. (2010) After the crisis: What now?, March [online] http://www-05.ibm.com/cz/study/pdf/GBE03288USEN.pdf (accessed 17 November 2016).

Bhagat, R.S., Kedia, B.L., Harveston, P.D. and Triandis, H.C. (2002) 'Cultural variations in the cross-border transfer of organizational knowledge: an integrative framework', Academy of Management Review, Vol. 27, No. 2, pp.204-221.

Björkman, I., Barner-Rasmussen, W. and Li, L. (2004) 'Managing knowledge transfer in MNCs: the impact of headquarters control mechanisms', Journal of International Business Studies, Vol. 35, No. 5, pp.443-455.

Björkman, I., Stahl, G. and Vaara, E. (2007) 'Cultural differences and capability transfer in cross border acquisitions: the mediating roles of capability complementarity, absorptive capacity and social integration', Journal of International Business Studies, Vol. 38, No. 4, pp.658-672.

Bosch-Sijtsema, P.M. and Postma, T.J. (2010) 'Governance factors enabling knowledge transfer in interorganisational development projects’, Technology Analysis and Strategic Management, Vol. 22, No. 5, pp.593-608.

Bresman, H., Birkinshaw, J. and Nobel, R. (1999) 'Knowledge transfer in international acquisitions', Journal of International Business Studies, Vol. 30, No. 3, pp.439-62.

Brouthers, K.D. (2002) 'Institutional, cultural and transaction costs influences on entry mode choice and performance', Journal of International Business Studies, Vol. 33, No. 2, pp.203-221.

Burkitt, L. (2014) Best Buy to Exit China, Wall Street Journal, 4 December [online] http://www.wsj.com/articles/best-buy-to-exit-china1417678576 (accessed 23 September 2016).

Business Bloomberg News (2011) Best Buy Shuts China Stores to Expand Five Star Retail Brand, 22 February [online] http://www.businessweek.com/news/2011-02-22/best-buy-shutschinastores-to-expand-five-star-retail-brand.html (accessed 30 March 2011).

Butterworth, M. (2008) 'Financial crisis: retailers face worse conditions for 30 years', Telegraph [online] http://www.telegraph.co.uk/finance/financialcrisis/3111382/Financial-crisis-Retailersfaceworse-conditions-for-30-years.html (accessed 6 August 2017). 
Capron, L. (1999) 'The long-term performance of horizontal acquisitions', Strategic Management Journal, Vol. 20, No. 11, pp. 87-1018.

Capron, L. and Pistre, N. (2002) 'When do acquirers earn abnormal returns?', Strategic Management Journal, Vol. 23, No. 9, pp.781-794.

Capron, L., Dussauge, P. and Mitchell, W. (1998) 'Resource redeployment following horizontalacquisitions in Europe and North America 1988-1992', Strategic Management Journal, Vol.19, No. 7, pp.631-662.

Carrefour S.A. (2011) Carrefour Financial Report 2011 [online] http://www.carrefour.com/ content/annual-reports (accessed 20 November 2016).

Carrefour S.A. (2012) Registration Document Annual Financial Report [online] $\mathrm{http}: / /$ www.carrefour.com/content/annual-reports (accessed November 20 2016).

Carrefour S.A. (2015) CARREFOUR - 2015 Annual Activity and Responsible Commitment Report [online] http://www.carrefour.com/content/annual-reports.

Carrefour, S.A. (2014) Completion of Agreements with Klépierre and Creation of CARMILA, 16 April, [online] http://www.carrefour.com/news-releases/completion-of-agreements-withklepierre-and-creation-of-carmila (accessed 1 July 2017)

Chen, C.J. (2004) 'The effects of knowledge attribute, alliance characteristics and absorptive capacity on knowledge transfer performance', R\&D Management, Vol. 34, No. 3, pp.311-321.

Corsetti, G., Pesenti, P. and Roubini, N. (1999) 'What caused the Asian currency and financial crisis?', Japan and the World Economy, Vol. 11, No. 3, pp.305-373.

Daneshkhu, S. (2012) Plassat Sets Out Carrefour Recovery Plan, 9 July [online] https://www.ft.com/content/39b746c0-bc81-11e1-a470-00144feabdc0 (accessed 03 November 2016).

Dauer, U. (2014) Rewe To Sell 53 Italian Billa Retail Outlets To Carrefour, 30 June [online] http://www.wsj.com/articles/rewe-to-sell-53-italian-billa-retail-outlets-to-carrefour1404149288 (accessed 11 November 2016).

Dawson, J. (2003) 'Towards a model of the impacts of retail internationalization', in Dawson, J., Mukoyama, M., Choi, S.C. and Larke, R. (Eds.): The Internationalisation of Retailing in Asia, pp.89-209, Routledge, London.

Dvorak. P. (2009) 'Clarity is missing link in supply chain', Wall Street Journal, May, Vol. 253, No. 115 , p.A1.

Eisenhardt, K. (1989) 'Building theories from case study research', Academy of Management Review, Vol. 14, No. 4, pp.532-550.

Erramilli, M.K. and Rao, C.P. (1993) 'Service firms' international entry-mode choice: a modified transaction-cost analysis approach', Journal of Marketing, Vol. 57, No. 3, pp.19-38.

FierceRetail: Metro Group, Kraft, Nestle and Proctor and Gamble Hook up in Russia with Data Sync Deal (2008) Questex, 27 December [online] https://www.fierceretail.com/operations/ metro-group-kraft-nestle-and-p-g-hook-up-russia-data-sync-deal (accessed 1 November 2010).

Geringer, J. (1998) 'Assessing replication and extension. A commentary on Glaister and Buckley: measures of performance in UK international alliances', Organization Studies, Vol. 19, No. 1, pp.119-138.

Goerzen, A. and Makino, S. (2007) 'Multinational corporation internationalization in the service sector: a study of Japanese trading companies', Journal of International Business Studies, Vol. 38, No. 7, pp.1149-1169.

Grant, R.M. (1996) 'Toward a knowledge-based theory of the firm', Strategic Management Journal, Vol. 17, No. S2, pp.109-122.

Griffith, D.A., Noble, S.M. and Chen, Q. (2006) 'The performance implications of entrepreneurial proclivity: a dynamic capabilities approach', Journal of Retailing, Vol. 82, No. 1, pp.51-62, DOI: 10.1016/j.jretai.2005.11.007.

Groot, T. and Merchant, K. (2000) 'Control of international joint ventures', Accounting, Organizations and Society, Vol. 25, No. 6, pp.579-607. 
Hansen, S. (2012) How Zara Grew Into the World's Largest Fashion Retailer?, 9 November [online] from http://www.nytimes.com/2012/11/11/magazine/how-zara-grew-into-the-worldslargest-fashion-retailer.html?_r=0 (accessed 29 September 2016).

Hartley, J.F. (1994) 'Case studies in organizational research. In qualitative methods in organizational research', in Casset, C. and Symon, G. (Eds.): A Practical Guide, pp.208-229, Sage, London.

Haspeslagh, P. and Jemison, D.B. (1991) Managing Acquisitions: Creating Value through Corporate Renewal, The Free Press, New York, NY.

History Sungjoo Group (2017) History 2000 1990 [online] http://www.sungjoogroup.com/en/ about/history.asp (accessed October 30 2010).

Huang, Y. and Sternquist, B. (2007) 'Retailers' foreign market entry decisions: an institutional perspective', International Business Review, Vol. 16, No. 5, pp.613-629.

Hunt, S.D. (1997) 'Resource-advantage theory: an evolutionary theory of competitive firm behavior?', Journal of Economic Issues, Vol. 31, No. 1, pp.59-77.

IBM (2009) Carrefour Strengthens Customer Loyalty and Its Brand with a New Promotions Strategy, 20 February [online] ftp://ftp.software.ibm.com/software/solutions/pdfs/ODC03121USEN-00_Carrefour_final_SP_Feb20-09.pdf (accessed 30 November 2016).

Inkpen, A.C. and Dinur, A. (1998) 'Knowledge management processes and international joint ventures', Organisation Science, Vol. 9, No. 4, pp.454-468.

Jiacheng, W., Lu, L. and Francesco, C.A. (2010) 'A cognitive model of intra-organizational knowledge sharing motivations in the view of cross-culture', International Journal of Information Management, Vol. 30, No. 3, pp.220-230.

Johansson, J. and Vahlne, J-E. (1977) 'The internationalization process of the firm: a model of knowledge development and increasing foreign market commitments', Journal of International Business Studies, Vol. 8, No. 1, pp.23-32.

Johansson, J. and Vahlne, J-E. (1990) 'The mechanism of internalization', International Marketing Review, Vol. 7, No.4, pp.11-24.

Jonsson, A. and Elg, U. (2006) 'Knowledge and knowledge sharing in retail internationalization: IKEA's entry into Russia', International Review of Retail, Distribution and Consumer Research, Vol. 16, No. 2, pp.239-256.

Karim, S. and Mitchell, W. (2000) 'Path-dependent and path-breaking change: reconfiguring business resources following acquisitions in the US medical sector, 1978-1995', Strategic Management Journal, Vol. 21 Nos. 10-11, pp.1061-1081.

Khan, M. and Roy, S. (2013) 'Strategic management of knowledge in globally distributed information technology firms: a case study', International Journal of Technology Marketing, Vol. 8, No. 4, pp.369-385.

Kim, D. (2007) Samsung Tesco Homeplus, Hankuk Kyungjai [online] http://www.hankyung.com/ news/app/newsview.php?aid=2007092679951\&sid=01040105\&nid $\backslash$ (accessed 27 September 2007).

King, D.R., Dalton, D.R., Daily, C.M. and Covin, J.C. (2004) 'Meta-analyses of post acquisition performance: indications of unidentified moderators', Strategic Management Journal, Vol. 25, No. 2, pp.187-200.

Kogut, B. (1998) 'Joint ventures and the option to expand and acquire', Management Science, Vol. 37, No. 1, pp.19-33.

Kogut, B. and Zander, U. (1992) 'Knowledge of the firm, combinative capabilities and the replication of technology', Organisation Science, Vol. 3, No.3, pp.383-397.

Kogut, B. and Zander, U. (1993) 'Knowledge of the firm and the evolutionary theory of the multinational enterprise', Journal of International Business Studies, Vol. 24, No.4, pp.625-646.

Kulatilaka, N. and Perotti, E.C. (1998) 'Strategic growth options', Management Science, Vol. 44, No. 8, pp.1021-1031. 
Larsson, R. and Finkelstein, S. (1999) 'Integrating strategic, organizational and human resource perspectives on mergers and acquisitions: a case survey of synergy realization', Organisation Science, Vol. 10, No. 1, pp.1-26.

Lopez, C. and Fan, Y. (2009) 'Internationalisation of the Spanish fashion brand Zara', Journal of Fashion Marketing and Management: An International Journal of Fashion Marketing and Management, Vol. 13, No. 2, pp.279-296, DOI: 10.1108/13612020910957770.

Lu, C. (2014) Zara Supply Chain Analysis - The Secret behind Zara's Retail Success, 4 December [online] https://www.tradegecko.com/blog/zara-supply-chain-its-secret-to-retail-success (accessed 30 November 2016).

Makhija, M.V. and Ganesh, U. (1997) 'The relationship between control and partner learning in learning-related joint ventures', Organisation Science, Vol. 8, No. 5, pp.508-527.

March, J.G., Sproull, L.S. and Tamuz, M. (1991) 'Learning from samples of one of fewer', Organisational Science, Vol. 2, No. 1, pp.1-13.

McCoy, K. (2017) 'Moody's: Number of distressed retailers tops total during financial crisis', USA Today [online] https://www.usatoday.com/story/money/2017/06/09/moodys-numberdistressed-retailers-tops-total-during-financial-crisis/102626866/ (accessed 6 August 2017).

MicroStrategy (2004) MicroStrategy Honors Three Companies for Excellence in Enterprise-Class Business Intelligence, 11 February [online] http://ir.microstrategy.com/news-releases/newsrelease-details/microstrategy-honors-three-companies-excellence-enterprise-class (accessed 30 October 2010).

Nadolska, A. and Barkema, H.G. (2007) 'Learning to internationalise: the pace and success of foreign acquisitions', Journal of International Business Studies, Vol. 38, No. 7, pp.1170-1186.

Niederkofler, M. (1991) 'The evolution of strategic alliances: opportunities for managerial influence', Journal of Business Venturing, Vol. 6, No. 4, pp.237-257.

Nonaka, I. and Takeuchi, H. (1995) The Knowledge Creating Company: How Japanese Companies Create the Dynamics of Innovation, Oxford University Press, Oxford.

Osborne, M.J. (2003) An Introduction to Game Theory, Oxford University Press, New York.

Palmer, M. (2006) 'International retail joint venture learning', The Service Industries Journal, Vol. 26, No. 2, pp.165-187.

Parmigiani, A. and Mitchell, W. (2009) 'Complementarity, capabilities and the boundaries of the firm: the impact of within firm and interfirm expertise on the concurrent sourcing of complementary components', Strategic Management Journal, Vol. 30, No. 10, pp.1065-1091.

Parmigiani, A. and Mitchell, W. (2010) 'The hollow corporation revisited: can governance mechanisms substitute for technical expertise in managing buyer-supplier relationships?', European Management Review, Vol. 7, No. 1, pp.46-70.

Pennings, J.M. and Lee, K. (1999) 'Social capital of organization: conceptualization, level of analysis and performance implications', in Leenders, R.T.A.J. and Gabbay, S.M. (Eds.): Corporate Social Capital and Liability, pp.43-67, Kluwer, New York, NY.

Pennings, J.M., Lee, K. and Witteloostuijn, A. (1998) 'Human capital, social capital and firm dissolution', Academy of Management Journal, Vol. 41, No. 4, pp.425-440.

Pisano, G. (1988) Innovation Through Market Hierarchies and Joint Ventures: Technology, Strategy And Collaborative Arrangements In The Biotechnology Industry, Unpublished PhD Dissertation, University of California, Berkeley.

Ramirez, E. (2010) MCM's Eastern Makeover; The Wall Street Journal [online] http://online.wsj.com/article/SB10001424052748704784904575112120954931914.html (accessed 12 March 2010).

Reagans, R. and McEvily, B. (2003) 'Network structure and knowledge transfer: the effects of cohesion and range', Administrative Science Quarterly, Vol. 48, No. 2, pp.240-267.

Research Bureau, Economic Planning Agency (1998) The Japanese Economy in 2008, December [online] http://www5.cao.go.jp/99/f/kaiko-e/kaikoe.html (accessed 30 September 2016). 
Retail Technology: Metro Group Expands Internal Collaboration (2008) Chain Store Age, July, p.34 [online] http://www.chainstoreage.com (accessed 30 November 2010).

Reuters (2013) Fitch: Carrefour's Klepierre Malls Acquisition is Positive; No Immediate Rating Impact, [online] https://www.reuters.com/article/fitch-carrefours-klepierre-malls-acquisi/fitchcarrefours-klepierre-malls-acquisition-is-positive-no-immediate-rating-impactidUSFit68068920131217 (accessed 30 October 2017).

Roberti, M. (2009) 'Achieving Six Sigma retailing', RFID Journal [online] http://www.rfidjournal.com/article/view/4930 (accessed 30 October 2010).

Ronen, S. and Shenkar, O. (1985) 'Clustering countries on attitudinal dimensions: a review and synthesis', Academy of Management Review, Vol. 10, No. 3, pp.435-454.

Rowley, J. (2005) Building brand webs: Customer relationship management through the Tesco club card loyalty scheme', International Journal of Retail and Distribution Management, Vol. 33 , No. 3, pp.194-206.

Ruddick (2014) 'How Zara became the world's biggest fashion retailer', Telegraph [online] http://www.telegraph.co.uk/finance/newsbysector/retailandconsumer/11172562/HowInditexbecame-the-worlds-biggest-fashion-retailer.html (accessed 6 August 2017).

Russia is Next in the Move to Synchronise Data (2009) Supply Chain Standard: News Analysis, February, p.22 [online] http://www.supplychainstandard.com (accessed 7 August 2009).

Sarala1, R.M. and Vaara, E. (2010) 'Cultural differences, convergence and crossvergence as explanations of knowledge transfer in international acquisitions', Journal of International Business Studies, Vol. 41, No. 8, pp.1365-1390.

Shubik, M. (1972) 'On gaming and game theory', Management Science, Vol. 18, No.5, pp.37-53.

Spekman, R.E., Isabella, L.A. and MacAvoy, T.C. (2000) Alliance Competence: Maximizing the Value of Your Partnerships, John Wiley and Sons, New York.

Sternquist, B., Byun, B.S. and B. Jin (2004) 'Dimensionality of price: an Asian perspective', The International Review of Retail, Distribution and Consumer Research, Vol. 4, No. 1, pp.1-18.

Suh, Y. and Howard, E. (2009) 'Restructuring retailing in Korea: the case of Samsung-Tesco', Asia Pacific Business Review, Vol. 15, No. 1, pp.29-40.

Sung, E. and Sternquist, B. (2010) 'Strategic international joint venture: opportunity, expansion and longevity for retailers internationalization', Journal of Euromarketing, Vol. 19, No. 1, pp.5566.

Szulanski, G. (1996) 'Exploring internal stickiness: impediments to the transfer of best practice within the firm', Strategic Management Journal, Vol. 17, No. S2, pp.27-43.

Tortoriello, M., Reagans, R. and McEvily, B. (2012) 'Bridging the knowledge gap: the influence of strong ties, network cohesion and network range on the transfer of knowledge between organizational units', Organisation Science, Vol. 23, No. 4, pp.1024-1039.

Tsai, W. (2001) 'Knowledge transfer in intraorganizational networks: effects of network position and absorptive capacity on business unit innovation and performance', Academy Of Management Journal, Vol. 44, No. 5, pp.996-1004.

Vida, I., Reardon, J. and Fairhurst, A. (2000) 'Determinants of international retail involvement: the case of large US retail chains', Journal of International Marketing, Vol. 8, No. 4, pp.37-60.

Vidalon, D. (2013) Carrefour to Buy Shopping Malls in \$2.8 Billion Deal, 16 December [online] http://www.reuters.com/article/us-carrefour-klepierreidUSBRE9BF04420131216 (accessed 11 November 2016).

Yin, R. (1994) Case Study Research. Design and Methods, Sage, Thousand Oaks, CA.

Yoshioka, M. (2015) Overview of Japan's Youth Apparel Market, Okamoto, Y. (Ed.) October [online] http://www.buyusa.gov/japan/build/groups/public/@bg_jp/documents/webcontent/ bg_jp_092180.pdf (accessed 14 October 2016).

Zander, U. (1991) Exploiting a Technological Edge: Voluntary and Involuntary Dissemination of Technology, Institute of International Business, Stockholm. 
Zhao, H. and Zhu, G. (1998) 'Determinants of ownership preference of international joint ventures: new evidence from Chinese manufacturing industries', International Business Review, Vol. 7 , No. 6, pp.569-589.

Zhong, L. and Lahiri, S. (2009) 'International joint ventures and tax competition in an integrated Market', International Review of Economics and Finance, Vol. 18, No. 1, pp.38-44. 